\title{
The Role of Political Risk in Service Offshoring Entry Mode Decisions
}

\section{Carsten Hansen, Carlos Mena and Emel Aktas}

\begin{abstract}
This research investigates the effect of political risk on the offshore service industry. The study empirically examines how an extended political risk definition, operationalised into a model consisting of 12 political risk variables, helps predict location decisions across offshoring entry modes and activity types. The research focuses on captive offshoring and offshore outsourcing entry modes, and Information Technology Outsourcing (ITO), Business Process Outsourcing (BPO) and Knowledge Process Outsourcing (KPO) activity types. The research indicated that political risk factors accounted for $38 \%$ of the variability in offshore outsourcing flows, implying that concerns about service disruptions and/or cost implications of external uncertainties feature as a key factor in supplier selection and location decisions. The findings further confirm a positive relationship between institutional and regulatory factors in host locations, and the flow of offshoring activities with a high knowledge content. The research contributes to enhancing the explanatory ability of Transaction Cost Economics by re-operationalising the concept of political risk in the context of both offshore outsourcing and captive offshoring. For practitioners, these findings provide a clear indication of the political risks that can affect service offshoring decisions; for policymakers, they highlight the importance of strengthening institutional and regulatory factors to attract investment.
\end{abstract}

Keywords: Transaction Cost Economics, Regression Analysis, Offshoring, Outsourcing, Risk Management, Political Risk 


\section{Introduction}

The offshore service industry has traditionally been driven by the objective of identifying more cost-effective business process solutions through leveraging cost arbitrage and talent pools across regions (Cui et al. 2017; Dolgui and Proth 2013; Williamson 2008). Common examples of globally sourced services include labour-intensive call centres, remote information technology application maintenance work, and software development (e.g. Cui et al. 2017; Goo et al. 2008; Gopal and Koka 2010). As the business model for offshoring has matured, companies have proceeded to apply it to ever more complex and integrated global networks of interdependent subsidiaries or suppliers and geo-locations, improving efficiencies at the cost of increased exposure to political risk (Ang and Inkpen 2008; Asmussen et al. 2016; Contractor et al. 2010; Lewin et al. 2009).

While political risk is not a new phenomenon, the spread of offshoring has increased firms' exposure to various kinds of politically motivated actions that represent a direct challenge to the performance of offshoring strategies (Peng et al. 2008; Hätönen and Eriksson 2009). The emerging variety of these non-business risks include direct or indirect actions in the political environment of the host country, like license cancellation, governmental interference, confiscation of assets, and other political events, with various levels disruption potential (Palugod and Palugod 2011). The risks include security exposure linked to politically motivated riots, strikes, sabotage, and terrorism, impacting directly or indirectly on operational performance (Monaghan 2010).

There is no consensus definition of political risk in the offshoring literature, and as a result the term has been applied across a broad range of risk types and contexts (Alon et al. 2006; Alon and Herbert 2009). Despite the expanding literature base, no specific definition has yet been developed that considers the unique dimensions of political risk in global supply or service chains; 
instead, the literature provides a range of independent conceptualisations that fail to distinguish terms such as risk, uncertainty, and vulnerability (Manuj and Mentzer 2008).

Political risk has traditionally been referred to as "discontinuities" (Robock 1971; Kobrin 1981) and considered to be limited to actions of national governments (Kobrin 1979), mainly involving confiscation, contract repudiation, currency inconvertibility, discriminatory taxation, embargo, expropriation of property, nationalisation, or war risk (Howell 2007). While earlier definitions of political risk focused on the role and actions of national governments (Gilliespie 1989), actions in the political domain resulting in business losses no longer necessarily emanate from the government itself. Often national governments are not the authoritative source of loss problems, meaning that increasingly regional, provincial, state, and local governments are dealing with investors directly in ways that the national governments are unable to control (Howell 1992). Other external agents such as nationalistic buyers, suppliers, employees and other stakeholders can cause disruption outside the control of legitimate governments (Agarwal and Feils 2007; Hahn et al. 2009; Hanner 1979; Hansen et al. 2017).

A wider political risk definition needs to recognise that risk emanates from political processes which are influenced by various environmental variables or on-going change (Fitzpatrick 1983). On-going change, takes the form of continuous activities such as macroeconomic management and monetary policy, legislation, and social or political evolution, which affect the overall business environment (Chauhan et al. 2015; Clark and Tunaru 2003). As research has changed focus from risk events to sources of risk, definitions that conceptualise political risk as emanating from internal instability, anticipated and unanticipated government actions, or government discontinuities, all brought about by social, economic, or political 
imperatives in a country's internal or relevant external environment need to be applied (Chauhan et al. 2015; Fatehi-Sedeh and Safizadeh 1989). On this basis, political risk should not be seen in isolation but rather understood in the context of broader country risk, determined as a function of the economic and political events occurring at the sovereign or sub-sovereign level in a country that threaten firm profitability and are the result of forces and conditions external to the firm and its industry (Hahn et al. 2009; Oetzel 2005). On this basis, our research aims to expand the conceptualisation of political risk to be measured through a broader spectrum of dimensions, including indicators of host country bureaucracy, corruption levels, strength of legal systems, frequency of organised labour strikes and potential for loss of Intellectual Property (IP).

In this research we define political risk as "the exposure of offshoring companies to unprovoked interference of external agents, with or without governmental sanction, originating either within or outside the host country, resulting in the overall restriction of business operating conditions or the industry specific environment, and negatively impacting on the company's subsidiary or outsourcing supplier's ability to ensure continuity of service delivery with consistent quality and at agreed cost”. This extended definition allows a holistic approach to understanding political risk and explicit effects on various industry-specific offshoring entry modes, namely captive offshoring and offshore outsourcing. The definition also establishes a clear link with business operations, acknowledging that political events only become a risk if they have potential implications for business objectives.

Considering emerging global sourcing risks, the choice of entry mode, which refers to the “... institutional arrangement that makes possible the entry of a firm's products, technology, human skills, management, or other resources into a foreign country” (Root 1994, p.5), has 
become a fundamental decision that every firm engaging in international markets needs to address (Kulkarni 2001; Brouthers 2013). For this research, we consider two main forms of entry mode: offshore outsourcing, and captive offshoring. In offshore outsourcing, the firm transfers the internal production of goods or services to a third-party supplier to perform a task, function, or process (Sanders et al. 2007). In captive offshoring, the buying company engages through a fully owned subsidiary, or a joint venture partnership, maintaining ownership control, but sacrificing flexibility (Larsen et al. 2013).

Using a Transaction Cost Economics (TCE) lens, we intend to extend the spectrum of previous political risk research by identifying the political risks affecting offshoring decisions and evaluating their impact on entry mode choices. Specifically, the research is guided by the following research question: How do political risk factors influence the entry mode decisions in service offshoring?

The contribution of this paper is twofold: First, the research identifies the key political risks influencing offshoring location decisions and offers an updated conceptualisation of political risk, contributing to a deeper understanding of the effects of political risk across different types of service offshore outsourcing, namely Information Technology Outsourcing (ITO), Business Process Outsourcing (BPO), and Knowledge Process Outsourcing (KPO). Secondly, the research evaluates the impact of different political risk factors on offshoring entry mode decisions. 


\section{Theoretical Background and Hypothesis Development}

\section{Offshoring Entry Mode Decisions under Uncertainty and Risk}

While offshoring has traditionally been associated with manufacturing (e.g. Dekkers 2000; Dekkers 2011), the offshoring of services has seen a similar dramatic growth over the years, transforming the way businesses manage their operations through digitalisation and offshoring service processes (Hahn et al. 2009; Modarress and Ansari 2007). Offshored services have traditionally been classified either as an information technology (IT) service or as a business process service. If the services are outsourced to an external supplier, these services are referred to as Information Technology Outsourcing (ITO) or Business Process Outsourcing (BPO). The offshoring of services has evolved from mainly IT services towards business process services to gradually more knowledge-based services such as research and development (R\&D) (Palugod and Palugod 2011). The notion of R\&D can be defined as services related to the design and development of new or improved products and processes (Martinez and Garcia 2011), and termed Knowledge Processing, or Knowledge Process Outsourcing (KPO), if undertaken by an external supplier. The three outsourcing classifications compound specific industry structures and properties that potentially may vary in their exposure to political risk, hence this research maintains an industry specific distinction between ITO, BPO, and KPO.

While understanding key motivations for the firm to engage in offshoring is important, the determination of the most appropriate entry mode constitutes a critical component of any offshoring strategy (Kulkarni 2001). As stated by Miller (1992: 312) “A firm's strategy deals with the alignment of the organization to its uncertain environment and thereby organizational strategic choices determine a firm's exposure to uncertain environmental and organizational 
components that impact firm performance”. The analysis of the entry mode choice implies determining the degree of commitment that the investing company wants to assume in a given host country. The choice of entry mode is therefore considered one of the most critical decisions in offshoring with implications for organisational control, investment risk, and resource commitment required to ensure successful operations (Zhao, Luo, and Suh 2004).

The argument linking external uncertainty, political risk and entry mode choice is twofold: first, that risk plays a critical role in entry strategy formation; and second, that a multi-dimensional perspective of risk yields a more complete understanding of risk impact on risk strategy decisions (e.g. Brouthers 1995; Demirbag and Glaister 2010; Miller 1992; Werner et al. 1996). It has further been suggested that the influence of the uncertainty type on a firm's entry mode choice has not been sufficiently emphasised (Kulkarni 2001), and that the linkage between risk perceptions and strategic decisions has not been appropriately established (Brouthers et al. 2002; Chauhan et al. 2015).

Transaction Cost Economics (TCE) proposes that firms evaluate and adapt their structures of governance to economise and allows firms to decide between markets and hierarchies (Coase, 1937; Madhok, 2007; Williamson, 1975; 1985). Theorising about uncertainty and political risk in international business, has been largely based on the market failure paradigm, from which TCE originates; and previous literature has ascertained that TCE has served as the overriding perspective for theorising entry mode choice, and accordingly transaction-cost related covariates have been recognised as major determinants of entry mode decision (Zhao et al. 2004; Jahns, Hartmann and Bals 2006; Ellram et al. 2008; López-Duarte and Vidal-Suarez, 2010; MartinezNoya and Garcia-Canal, 2011). 
While other perspectives supplement the entry mode choice discussion, such as institutional theory, agency theory, and the resource-based view, the basis for this research is that entry mode choice is an economic decision, and the firm is expected to choose the entry mode that offers the highest risk-adjusted return on investment (Anderson and Gatignon, 1986). On this basis, the assessment of TCE determinants remains important as the alignment between entry mode and transaction properties has performance consequences for the firm and the offshoring operation (Zhao et al. 2004). In this context, political risk is addressed by weighing the costs and benefits of political governance structures, policies, and likely political risks in the host country. In the section that follows we will use this theoretical lens to articulate a series of hypotheses that help explain the relationship between political risk and entry mode.

\section{Hypotheses Development}

The term "uncertainty" has been used in the literature as a reference to the unpredictability or lack of data on environmental variables that have an impact on corporate performance (van Wyk 2010; Williamson 1985). The uncertainty of environmental variables reduces the predictability of corporate performance, increasing business risk exposure (Miller 1992). In the TCE literature, uncertainty tends to be categorised as the sum of internal uncertainty and external uncertainty (Erramilli, 1992), stating that both internal and external uncertainties surrounding a transaction will influence both location and entry mode choice. Previous work has confirmed that uncertainty in the international environment affects the choice of entry mode (Brouthers 1995; Demirbag and Glaister 2010; Miller 1992; Werner et al. 1996), suggesting that international uncertainty plays a 
critical role in entry strategy, and that a multi-dimensional perspective of uncertainty is required for risk management decisions (Brouthers et al. 2002).

On this basis, the research firstly explores the impact of political risk characteristics on offshoring activities by analysing the effect of political risk on offshoring location flows. Secondly, the research compares the extent to which offshore outsourcing and captive offshoring differ in sensitivity to political risk in offshore engagements. Hence, it is guided by the following hypothesis:

Hypothesis 1: The political risk factors that affect offshoring decisions for offshore outsourcing activities are different from those that affect captive offshoring activities.

We propose that inconclusive findings on uncertainty and subsequent entry mode choice are partly due to the non-diversified and simplistic operationalisation of the concept of political risk. The integration of mechanisms to capture institutional differentiations is one added dimension of an expanded conceptualisation of external uncertainty (Slangen and Tulder 2009; Zhao et al. 2004). It has further been suggested that the influence of the uncertainty type on a firm's entry mode choice has not been sufficiently explored (Kulkarni 2001), nor has the linkage between risk perceptions and strategic decisions (Brouthers et al. 2002). The determinants of offshoring flows are therefore suggested to be extended beyond traditional factors, such as government stability, internal/external conflict and ethnic tensions, to also include aspects of local corruption, quality of bureaucracy, and law and order (Busse and Hefeker 2007). 
Hypothesis 2: Institutional and regulatory factors in the host country are positively related to the volume of offshore outsourcing activities.

Transaction cost determinants are considered industry- and activity- specific (Graf and Mudambi 2005), underlining the need to employ a differentiated approach to various forms of offshore outsourcing activities, i.e., ITO, BPO, and KPO. As external uncertainties can have an impact on a firm at both industry- and country- specific levels, theoretical predictions will be subject to industry- and country- specific control variables. The industry's moderating effect on the impact of country risk may be eliminated if more dimensions of environmental uncertainty, such as protection of IP rights, can be captured in future empirical testing of the relationship between external uncertainty and offshoring (Zhao et al. 2004).

The research assumes that political risk exposure related to the loss of IP and contract enforcement risks become increasingly important as the knowledge content of services increases. On this basis, we further hypothesise that the knowledge content of the offshoring activity is a key distinction for political risk exposure and the corresponding choice of entry mode; i.e., offshore outsourcing versus captive offshoring. Hence services with a low knowledge content are assumed to be more comfortably outsourced to third parties, while services with a high knowledge content are maintained internally through a captive entry mode. This notion highlights the potentially moderating effect of specific outsourcing activities; i.e., ITO, BPO, or KPO, noting that firms tend to ensure more internal control for high value processing through captive engagement modes, rather than exposing the value content to a third-party supplier through outsourcing. 
These assumptions support the notion that when imperfect markets affected by bounded rationality and opportunism lead to higher transaction costs, an internal governance structure will be more attractive (Anderson and Gatignon 1986; Cui 2017; Kull et al. 2014). For example, in host countries with limited institutional capacity, local suppliers may use legal loopholes or bureaucracy to act with self-interest, constituting a risk of opportunistic behaviour. Consistent with the TCE perspective we hypothesise that companies will only engage in service offshoring with a high knowledge content in environments with a correspondingly high institutional and legal certainty. Hence, we hypothesise that:

Hypothesis 3: Institutional and regulatory factors in the host country are positively related to the volume of offshore outsourcing activities with a higher knowledge content (KPO).

\section{Research Design and Method}

In exploring dependence relationships between offshoring and political risk, our research applies a multivariate regression analysis. Multivariate regression is considered one of the preeminent techniques of multivariate analysis, which has as its purpose “... to measure, explain and predict the degree of relationship among variates (weighed combinations of variables)" (Hair et al. 2011: 3). Specifically, multivariate regression is used to determine the equation that describe the relations of a set of variables that respond simultaneously to changes in other variables (Hair et al. 2011). This is closely aligned with the objective of this research as we intend to understand how a set of political risk factors collectively influence the entry mode decisions in service offshoring. This technique not only is extensively used in economics and management research 
but also has been widely used to investigate topics related to offshoring and outsourcing (e.g. Broedner et al. 2009; Li et al. 2010; Luo et al. 2012; Mishra et al. 2017).

The regression analysis leverages a set of 12 political risk indicators as independent variables (Table 1). At a first level of analysis, the dependent variable was the volume of either offshore outsourcing or captive offshoring flows; at a second level of analysis, the dependent variable was the type of activity (ITO/BPO/KPO) (Table 2). The regression analysis identifies the independent variables that are statistically significant (Hair et al. 2011), highlighting political risks that most significantly predict flows into offshore destinations through either an offshore outsourcing or captive offshoring entry mode.

\section{Selection of Independent Variables}

The independent variables are drawn from previous qualitative research by Hansen et al. (2017) on political risk exposure perceptions across the offshore sourcing industry. Previous research used a repertory grid analysis technique to capture the frequency and perceived impact of these independent variables on offshoring engagements (Hansen et al. 2017). The research identified home country risk featuring as the dominant political risk concern for the industry, while for location decisions, it identified institutional indicators such as host country bureaucracy, corruption, staff safety, currency stability, efficiency of legal systems, frequency of organised labour strikes, and potential for loss of intellectual property (IP). In addition, political and socioeconomic concerns such as host government stability and social unrest were identified as key considerations (Hansen et al. 2017). 
The political risk categories identified by Hansen et al. (2017) are operationalised drawing on data extracted from the Global Competitiveness Index (GCI) developed by the World Economic Forum (WEF 2014), combined with data from the PRS Group Political Risk Index (PRSG 2014). The independent political risk variables are defined in Table 1, with $\mathrm{N}$ indicating the country assessments for each risk indicator category from 2006 to 2014 across 92 countries in the sample (See Appendix 1).

[Insert Table 1 near here].

The risk indicators are measured on a 1-7 scale (where a higher score suggests better performance) and vary in sample size as complete time series data are not available equally for all destinations. To overcome this challenge, the years with missing data were classified in SPSS as system-missing data values, allowing the research to run the regression analysis excluding data either list-wise or pair-wise. A comparative analysis was first run using the list-wise exclusion methodology resulting in 265 observations, and then with a pair-wise methodology yielding 458 to 828 observations. As using list-wise or the pair-wise exclusion had no significant impact on the key outcome of the analysis; therefore, the pair-wise exclusion approach was applied to benefit from larger samples.

\section{Selection of Dependent Variables}

One of the challenges with researching political risk in the context of the offshore outsourcing is the absence of existing data sets that match the applied definition as a unique entry mode form. The World Trade Organization (WTO) has previously used the International Monetary Fund (IMF) Balance of Payment (BoP6) statistics to assess the overall offshore services trade, to measure the 
impact of offshore outsourcing on employment (WTO 2005). The BoP6 statistics reflect the inflow and outflow of transactions in an economy consisting of "the institutional units that are resident in the economic territory of that economy" and "has the dimension of legal jurisdiction as well as physical location" (IMF 2007, 50). The BoP6 records the net position in terms of debits and credits of individual transactions, providing a net position of an economy in terms of trade in services. For this research, the BoP6 services account data, the credit exports of services, are used as the basis for determining the volume of offshore outsourcing activities being exported from a specific location. The research further used the sum of the three following BoP6 segments as the consolidated service offshoring export (credit) of the individual country, and the individual segments as a proxy for ITO, BPO, and KPO flows. This allowed us to compare the effect of political risk factors on offshore outsourcing versus captive outsourcing activities.

\section{Computer and information services (CIS)}

The BoP6 (IMF 2007) includes Computer and Information Services (CIS) as a sub-component of Telecommunications, Computer, and Information services. The CIS segment of the BoP6 includes computer services consisting of hardware and software related services and data-processing services (IMF 2007) and is used as a proxy for ITO.

The Other Business Services $(O B S)$ account provides the best available proxy for business and research process outsourcing flows (WTO 2005). Through the IMF database filtering mechanism in BoP6, the OBS data is divided into two categories relevant to offshore outsourcing research:

Research and development $(R \& D)$ : The $R \& D$ Services data reflect services that are associated with basic research, applied research, and the experimental development of new 
products and processes. Activities in the physical sciences, social sciences, and humanities are covered, including the development of operating systems that represent technological advances and commercial research related to electronics, pharmaceuticals, and biotechnology (IMF 2007). The data component is used as a proxy for Knowledge-based Outsourcing (KPO), as it captures the component of offshore outsourcing that includes outsourcing with a high knowledge content.

Remaining business services: A further subcategory of OBS includes "Business and other services", such as transport, construction, and computing, which may be subcontracted. These services are classified into the "appropriate specific service categories, computing, or other business services" (IMF 2007). By excluding the transport and construction services, and the computer and R\&D services, the residual flows in the OBS segment are used as a proxy for BPO. Per WTO (2005), for captive offshoring, few national statistics allow for the identification of crossborder transactions between affiliate and non-affiliate firms. Hence this research uses the FDI data drawn from the UNCTAD FDI statistics database (UNCTAD 2014) in line with previous political risk research (Busse and Hefeker 2007), as the basis for exploring captive offshoring.

Table 2 summarises the data sources for the dependent variables.

[Insert Table 2 near here].

The regression analysis was conducted in five rounds with the dependent variable set as either i) consolidated Aggregated Service offshore outsourcing per national economy (all-inclusive sample); or ii-iv) across activity types (ITO/BPO/KPO) export per national economy or finally as v) captive offshoring. All variables were standardised before running the regression analyses to eliminate scale effects. 


\section{Results}

\section{Political Risk across Aggregate Offshore Outsourcing}

In the analysis of aggregate offshore outsourcing flows, the political risk variables were inserted into the regression analysis randomly, using a forced entry approach. The 12 political risk indicators were ranked in accordance with the absolute value of the standardised Beta coefficients allowing for a direct comparison of relative importance with the global offshore outsourcing flows. Table 3 presents the regression results for aggregate global flows highlighting Beta coefficients, tvalues, and significance levels.

[Table 3 near here].

The findings suggest that the 12 political risk indicators account for $38 \%\left(\mathrm{R}^{2}\right)$ of the variation in offshore outsourcing flows, and with an F-ratio of $22.151(\mathrm{p}<.001)$, suggesting that the regression is significant. The method applied further allowed for a classification of the individual risk indicators' impact on offshore outsourcing flows, providing an indication of relative importance across the spectrum of political risks. Of the 12 political risk indicators included in the regression, five were significant: IP protection, burden of customs procedures, quality of bureaucracy, internal conflict, and geopolitical risk. The results indicate that for each unit of increase in IP protection, the offshore outsourcing export from the host country increases by 0.692 units, suggesting a high level of sensitivity by the offshore industry to IP protection in their location decisions. Similarly, for each unit of increase in quality of bureaucracy, the offshore outsourcing flow increases by 0.305 units. On the other hand, outsourcing exports from the host country decreases when there is an improvement in the burden of customs, internal conflict, and reduction of geopolitical risk. While this might appear counter-intuitive, the findings suggest that the 
political risk determinants for offshore outsourcing location decisions are mainly focused on institutional and regulatory factors, while traditional consideration of internal and external instability has a less significant role and concerns are overruled by cost saving potential.

The Durbin-Watson statistic at .411 suggests a possible positive correlation between adjacent residuals in the model or positive autocorrelation, possibly instigated by using time series data. A collinearity analysis further indicated that at this stage there was likely to be collinearity between three indicators; namely, efficiency of legal frameworks, judicial independence, and corruption. We then checked the Variance Inflation Factors (VIF) for all indicators in the regression. None of the VIF were higher than 10 (Hair et al. 2010), hence we kept the indicators in the regression.

\section{Political Risk across Offshore Outsourcing Typologies}

As with the aggregated volumes of offshore outsourcing flows, the same methodology was applied to each of the ITO, BPO, and KPO data sets to determine the relative importance of political risk variables across these specific segments of offshore outsourcing activities. The results for ITO offshore outsourcing given in Table 4 indicate that export increases by 0.265 units for each unit of increase in quality of bureaucracy, by 0.177 units for each unit of increase in level of cooperation in labour-employer relations, and by 0.292 units for each unit of increase in judicial independence levels. However, ITO exports decrease by 0.416 units for every unit of improvement in internal conflict levels and by 0.260 for every improvement in the burden of customs procedures.

[Table 4 near here]. 
The results for BPO related offshore outsourcing in Table 5 indicate that exports from the host country increase by 0.744 units for each unit of increase in the levels of IP protection, by 0.241 for every unit increase in quality of bureaucracy, and by 0.200 units for every unit of improvement in corruption levels. Similarly, the findings indicate that exports decrease by 0.329 units for each unit of improvement in the burden of customs procedures, and by 0.154 units for each unit of improvement in geo-political risk at the host location. This is in line with the responses of the dependent variable to the changes in the burden of customs procedures and external conflict in the analyses for aggregated outsourcing (Table 3) and ITO (Table 4) volumes.

[Table 5 near here].

The results for the impact of political risk in KPO-related offshore outsourcing in Table 6 indicate that exports increase by 0.935 units for each unit of increase in the level of IP protection at the host location. Similarly, the findings indicate that exports of KPO-related offshore outsourcing decrease by 0.505 units for each unit of improvement in burden of customs procedures and by 0.265 units for every unit of improvement in staff security levels at the host location.

[Table 6 near here].

Compared to the aggregated offshore outsourcing, ITO, BPO, and KPO flows are explained by three significant independent variables of political risk indicators. Similar to BPO, KPO flows are significantly determined by the level of intellectual property protection in the host country, suggesting that both BPO and KPO have significant knowledge content. The direction of burden of customs procedures could be explained in a similar manner, as was explained in the aggregate 
analysis, namely that companies choose to operate in imperfect business environments due to the cost benefit trade-offs. The reason for a negative impact of staff security on KPO flows could be explained by a variable not included in the regression: cost of labour. The cost of labour for highly educated staff in countries with high security is relatively higher, while companies can access similarly educated staff at lower cost, in the context of environments with higher insecurity.

\section{Political Risk and Captive Offshoring flows}

Following the same methodology as for the aggregated offshore outsourcing data, the political risk variables were analysed against the captive offshoring flow data. The findings in Table 7 highlight the individual risk indicators' impact in the context of captive offshoring. The results indicate that volume increases by 0.733 units for each unit of increase in IP protection, by 0.269 for each unit of increase in the quality of bureaucracy, and by 0.215 units for every unit of improvement in corruption levels. On the other hand, flows decrease by 0.353 units for every unit of improvement in judicial independence, by 0.312 units for every unit improvement in burden of customs procedures, by 0.154 for every unit increase in geopolitical risk, and finally by 0.184 units for every improvement in staff security concerns.

[Table 7 near here].

Having considered the analysis for aggregated offshore outsourcing, ITO, BPO, and KPO, the directions of the coefficients for judicial independence, burden of customs procedures, external conflict, and staff security in the regression analysis of the captive offshoring are not a surprise. There are possible non-political risk-related factors confounding these indicators, which are 
usually highly correlated with the GDP and the labour costs of the host country. The value of the $\mathrm{R}^{2}$ is stated as .291 , indicating that the 12 political risk indicators account for a total of $29.1 \%$ of the variation in captive offshoring flows.

\section{Discussion}

The research applied a multiple linear regression methodology for both offshore outsourcing export data and captive offshoring flows, ranking the 12 key political risk variables in accordance with their ability to predict offshoring inflows to various host locations. Three hypotheses are tested and the results in Table 8 are concluded. The results confirm that political risk, in the choice of outsourcing supplier locations, is a relevant and important factor in determining supplier and location choice.

Of the 12 political risk indicators included in the regression, five were significant for offshore outsourcing engagements as an entry mode, namely: IP protection, burden of customs procedures, and quality of bureaucracy, internal conflict, and external conflict. The results indicate that for each unit of increase in IP protection and quality of bureaucracy, the level of exports from the host country increases, suggesting a high level of sensitivity by the offshore industry to institutional and regulatory factors in their location decisions.

Surprisingly, results also show that offshore outsourcing flows from the host country decrease when there is an improvement in burden of customs and external conflict. Although these results may appear counterintuitive at first, they could be explained by factors that are not politicalrisk-related and hence not included in the analysis. Most offshore outsourcing is toward those countries that perform poorly across these indicators, due to other reasons such as lower labour 
costs; hence the regression suggests a negative relationship between these political risk indicators and the outsourcing flows. The findings suggest that the operating environment in which offshore outsourcing is taking place is often impacted upon by burdensome customs regulations and potential for conflict. The political risk exposure can be seen in the context of trade-offs with labour cost arbitrage and lower operating costs, highlighting the potential for disruption in service chains if not monitored and managed.

Similarly, the results suggest a positive correlation between captive offshoring flows and IP protection, quality of bureaucracy, including corruption levels. The model indicates a negative relationship between geopolitical risks, staff security, burden of customs procedures and judicial independence. Compared with the findings from the offshore outsourcing activities, the findings suggest a consistent overlap of key substantial variables, including IP protection, quality of bureaucracy and burden of customs procedures - all significant for both outsourced and captive offshoring. This significant finding emphasises that institutional and regulatory factors in the host country are essential to both offshoring activities.

The findings further suggest that both forms of offshoring activities operate in external environments characterised by high levels of customs burdens and instability. It should be noted that flows associated with both outsourcing and captive activities appear related to environments that are considered vulnerable to geopolitical risk. This negative correlation suggests that most offshoring activities, whether captive or outsourced, take place in developing economies to leverage cost arbitrage, and that companies are identifying strategies and developing capabilities to deal with these challenges (Barney 1999). 
The results can be considered as statistically significant and partially supporting H1, that "The political risk factors that affect offshoring decisions for offshore outsourcing activities are different from those that affect captive offshoring activities". The important distinction between offshore outsourcing and captive offshoring is that political risk exposure is linked to the nature or type of political risks being considered. While the findings suggest that both offshore outsourcing and captive offshoring are equally sensitive to institutional and regulatory factors relating to IP protection, quality of bureaucracy, risks related to staff security, corruption and judicial independence are more significant in activities with a physical presence.

The research further set out to determine if concerns with institutional and regulatory factors have an impact on offshore outsourcing flows in terms of engagement location. The results confirm a positive and significant relationship between offshore outsourcing flows and IP protection and quality of bureaucracy. Similarly, the negative and significant relationship between the burden of customs procedures and offshore outsourcing flows further confirms, together with internal and external conflict and government stability variables, that offshore outsourcing engagements extend into often unstable and unpredictable environments. Overall, the results lend partial support to $\mathrm{H} 2$ stating that "The institutional and regulatory factors in the host country are positively related to the volume of offshore outsourcing activities". However, the results allow us to conclude that the multi-dimensionality of political risk causes a bidirectional effect on offshoring volumes, confirming the need for a more nuanced definition of the construct.

The research finally explored the association between knowledge-based outsourcing (KPO) inflows and institutional capacity, i.e., legal enforcement of IP rights and contracts in the host location. The research assumed that if the institutional capacity rises, the willingness to engage in 
offshore outsourcing with a higher knowledge content will also increase. For this purpose, the research explored the impact of political risk variables across three identified types of offshore outsourcing, i.e., ITO/BPO/KPO to present a comparative analysis. The analysis yielded $\mathrm{R}^{2}$ values for ITO: .267, BPO: .368. and KPO: .277.

The findings suggest a consistent concern with the quality of bureaucracy for both ITO and BPO engagements, while this was not found to be a significant indicator for KPO engagements. However, IP protection was by far the most significant variable for KPO with a coefficient of 0.935, and for BPO at 0.744, while non-significant for ITO engagements. Across the three offshore outsourcing activities, the impact of the burden of customs procedures was significant for all, with the largest coefficient for KPO engagements. The results further highlighted judicial independence to have a positive and significant correlation with ITO, a negative and significant correlation with BPO, and no correlation with KPO.

In terms of activity-specific findings, ITO has a positive and significant correlation with cooperation in labour-employer relations, suggesting higher sensitivity to labour relations due to possible higher labour intensity of the engagement type. Similarly, BPO has a positive and significant correlation with corruption, and KPO with staff security.

The indication of a negative relationship between ITO and internal conflict suggests that ITO activities are more often outsourced to locations more exposed to internal conflict. One reason for this could be that the nature of the ITO activities is easier to divert in the case of unrest and/or be completed through home-based arrangements as part of a business continuity plan. A post hoc review of the dependent variable data also highlights that ITO outsourcing remains dominated by 
the India market, which by the PRSG data is classified as prone to internal conflict, highlighting the need for more detailed location classifications.

The finding that BPO activities have a positive relationship with the quality of bureaucracy suggests that typical BPO activities, such as the management of call centres and back-office support activities, is more labour-intensive and requires more regulatory engagement with governments for the local suppliers of services. As BPO outsourcing contracts often become more integrated and require more long term and in-depth relationships, it would make sense that corruption and bureaucracy-related issues are more of a collective concern and hence a shared problem with the service buyer. Similarly, to leverage cost arbitrage for labour-intensive backoffice work, offshore outsourcing would often take place in regions characterised by geopolitical tension, but less so by internal conflict, which could cause service delivery problems for the BPO activity.

As expected, the KPO segment came out with a significantly positive relationship with the strength of IP rights frameworks to protect any R\&D activities conducted by the outsourcing companies. A more detailed review of KPO flows highlights that most KPO activities are directed to locations such as the United States, Germany, Canada, and other EU locations. Overall, the results can be considered as statistically significant, indicating a strong statistical relationship between KPO flows and institutional capacity to protect against IP loss. More surprisingly, IP rights protection also has the highest coefficient for BPO, suggesting that BPO service delivery has an increasingly high knowledge content of concern for the buyers of offshore outsourcing services. While the findings are statistically significant, the research cannot establish direct causality between the parameters and therefore partly supports H3: "The level of institutional and 
regulatory factors in the host country is positively related to the volume of offshore outsourcing activities with a higher knowledge content (KPO)". The findings suggest that to attract KPO activities, the location needs to ensure the presence of an appropriate IP regulatory framework.

[Table 8 near here].

\section{Contributions, Implications, and Further Research}

This research focused on political risk, a central construct in determining ownership, and locational and internalisation attractions (Agarwal and Feils 2007; Agarwal and Ramaswami 1992; Dunning 1980; 2000). The aim was to analyse the implications of political risk in the context of offshore outsourcing and captive offshoring. A review of the literature suggested that previous political risk research has generally been limited to captive offshoring, because these operations represent a more complex investment form than that of offshore outsourcing (Agarwal and Feils, 2007). The perception has been that since offshore outsourcing entry mode has less capital at stake, and no physical facilities at risk, political risk consideration should be of less significant concern. On that note, there has been an absence of an analytical framework that goes beyond captive offshoring and that can adequately contribute, either in a taxonomic or operational sense, to improving political risk management within the offshore outsourcing sector.

\section{Implications for Theory}

While TCE has been the main theoretical framework for the conversation on political risk and offshoring, the theory and its corresponding empirical findings have not been conclusive on 
how political risk impacts on offshoring location and entry mode decisions. This research has offered a new conceptualisation and operationalisation of the political risk construct, allowing for more granularity in the differentiation between various dimensions of formal uncertainty and their implications for offshoring. The identification of more relevant political risk factors, such as institutional frameworks, support emerging criticism contending that construct needs to be conceptualised more broadly and to incorporate the wider concept of governance infrastructure (Slangen and Tulder 2009; Zhao et al. 2004).

The findings confirm the importance of incorporating industry-specific moderators into TCE-based entry mode perceptions of external uncertainty. All TCE determinants are industryspecific, underlining the need to apply a differentiated approach to offshore outsourcing i.e., across ITO, BPO, and KPO activities. A review of the relationship with key political risk variables across offshore outsourcing engagements confirms that the offshore outsourcing industry cannot be assessed as one holistic group in terms of risk exposure, but should be reviewed through the lens of its activities. This affirms that external uncertainty exposure is moderated by industry type and activity and needs to be systematically incorporated into the notion of external uncertainty and its impact on entry mode.

The findings also have implications for other TCE constructs, such as bounded rationality, opportunism, and asset specificity. The research validated that institutional capacity, such as legal enforcement of IP rights and contract enforcement, becomes increasingly important as the knowledge content increases. These findings support the TCE notion that cases where the market is imperfect due to bounded rationality and opportunism, leading to increased transaction costs due to uncertainty, an internal governance structure will be considered more attractive (Anderson 
and Gatignon, 1986). For example, in host countries with limited governance infrastructure or institutional capacity, local suppliers may use loopholes in the legal system or bureaucracy to act in self-interest, hence constituting a risk of opportunistic behaviour.

The research also impacts the notions of asset specificity and opportunism, which are considered key factors in explaining vertical integration (Williamson 1985). TCE suggests that when asset specificity increases, the "balance shifts in favour of internal organisation" (Williamson 1985, 90). In the context of service offshoring, the research proposes to introduce the concept of knowledge specificity to be considered as an additional determinant of vertical integration decisions.

The research is in line with the call for further research on the questions of how and where to source (Asmussen et al. 2016; Kotabe and Murray 2004). While the political risk research to date is extensive, research remains unable to analytically disentangle causality between political risk types and their impact on investment strategies.

\section{Implications for Practice and Policy}

At a practical level, the findings form the basis for developing a differentiated political risk map of typologies that can capture the nuances in offshoring risks, allowing for a more accurate risk assessment of various offshoring locations and the effective monitoring of post-contractual political risk exposure. In an era of changing geo-politics and populist challenges to the political establishments in the US and Europe, there is an increasing need to understand and navigate the new emerging political environment. Policy discussions around limiting US H1B visas, data privacy restrictions and a general reversal of the mechanisms of globalisation are impacting the 
underlying cost assumptions of the offshoring business model, in both host and buyer countries. In this new and emerging political environment, the research provides the basis for developing a more relevant weighted offshore outsourcing risk index to support the industry in developing risk informed location decisions. The index can serve as a tool for location decisions, for both captive offshoring and supplier selection, plus provide continued post-contract monitoring of changes in underlying risk indicators.

The research further allows for assessments across offshore engagement types, both in terms of entry mode and value-content, enabling detailed industry-specific risk assessments focusing on the risks with the highest potential impact on that specific engagement type. The visibility on industry-specific risk exposure will help companies more confidently navigate and monitor the political environment in which they need to operate. Similarly, the research findings provide a guide for governments for attracting offshoring activities, by understanding the underlying concerns of the industry, and the potential pull effects of different policy interventions. The findings further allow for targeting certain types of offshoring, for example some governments are keen on attracting KPO activities, while less interested in ITO and BPO types of engagements. The granularity of the research findings allows for more detailed industry development plans and targeted investments that match the development agenda of host countries.

As potential host countries compete to attract offshore outsourcing activities to enhance employment and knowledge transfer opportunities into their economies, it would be prudent for policymakers to take note of the importance of strengthening institutional and regulatory factors. If a host country is seeking to attract outsourcing within the areas of $R \& D$, it would be especially 
important to ensure that the appropriate IP regulatory frameworks are in place, while for more labour-intensive ITO activities, a well-functioning labour market would have a higher impact.

\section{Limitations and Further Research}

While the findings indicate a predictive ability of the identified political risk indicators at a consolidated level of $38 \%$, suggesting political risk is a valid consideration, there are a range of additional potential moderators pertaining to the external business environment, prior firm experience, and business volume. The findings indicate that the premises of TCE alone may be insufficient to explain a firm's location decisions or whether to follow offshore outsourcing or captive offshoring entry mode when offshoring ITO, BPO, or KPO business processes. Further research should investigate complementary theories such as Agency Theory, Social Exchange Theory, and the Resource Based View, to construct more comprehensive explanations of the service offshoring phenomenon. Similarly, previous operationalisations of TCE have not appropriately factored in the conditioning effect of the risk adaptive behaviour of firms. It would be valuable to develop a comprehensive model, including a full range of internal and external variables, to enhance the predictability of firm location and entry mode decisions.

\section{Conclusions}

This research set out to determine how political risk factors affect service offshoring entry mode decisions; adopting a broad definition of political risk which included institutional and regulatory factors. The research confirmed that political risk is a genuine issue of concern in offshore outsourcing, despite technically being a means of "outsourcing" risk to suppliers. The research 
indicated that the 12 identified political risks accounted for $38 \%$ of the variability in offshore outsourcing flows, implying that concerns about service disruptions and/or cost implications of external uncertainties feature as a factor in supplier and location decisions. This expanded definition of political risk contributes to TCE by providing a more comprehensive and nuanced conceptualisation of the construct.

The findings highlight a consistent overlap of key predictive variables, including IP protection; quality of bureaucracy, and burden of customs for both offshore outsourcing and captive offshoring activities. This is a significant finding as it shows that institutional and regulatory factors in the host country are a key concern for offshoring in general. The important distinction between offshore outsourcing and captive offshoring activities is more specifically related to the kinds of political risk. The research yielded significant and positive relationships with IP protection and bureaucracy, for both entry modes, while captive offshoring activities were also significantly associated with security related variables, such as staff security and internal conflict.

The research offers an expanded conceptualisation of political risk in the context of offshoring. This reconceptualisation shows good promise for improved predictive ability in the choice of offshoring entry mode, and as a result has significant implications for theory, practice, and policy. We hope the research serves as a stepping stone for researchers, practitioners, and policymakers concerned with the risk implications of offshoring. 


\section{REFERENCES}

Agarwal, J. and D. Feils. 2007. "Political Risk and the Internationalization of Firms: An Empirical Study of Canadian-based Export and FDI Firms." Canadian Journal of Administrative Sciences 24 (3): 165-181.

Agarwal, S. and S. Ramaswami. 1992. "Choice of foreign market entry: impact of ownership, location and internationalization factors." Journal of International Business Studies 33(1): 517 551.

Ang, S. and A.C. Inkpen. 2008. "Cultural intelligence and offshore outsourcing success: A framework of firm-level intercultural capability.” Decision Sciences 39(3): 337-358.

Anderson, E. and H. Gatignon. 1986. "Modes of Foreign Entry: A Transaction Cost Analysis and Propositions.” Journal of International Business Studies 17(3): 1-26.

Arnold, U. 2000. "New dimensions of outsourcing: a combination of transaction cost economics and the core competencies concept." European Journal of Purchasing and Supply Management 6(1): 23-29.

Asmussen, C.G., M.M. Larsen, and T. Pedersen. 2016. "Organizational Adaptation in Offshoring: The Relative Performance of Home- and Host-based Learning Strategies." Organization Science, 27(4): 911-928.

Aubert, B.A., S. Rivard, and M. Patry. 1996. "A transaction cost approach to outsourcing behavior: some empirical evidence." Information \& Management 30(2): 51-64.

Barney, J. 1991. "Firm resources and sustained competitive advantage." Journal of Management 17(1): 99-120.

Barney, J. B. 1999. "How a firm's capabilities affect boundary decisions.” Sloan Management Review 40(3): 137-149.

Barthelemy, J., 2003. "The seven deadly sins of outsourcing." The Academy of Management Executive 17(2): 87-98.

Broedner, P., S. Kinkel, and G. Lay. 2009. "Productivity effects of outsourcing: new evidence on the strategic importance of vertical integration decisions." International Journal of Operations \& Production Management 29(2): 127-150. 
Brouthers, K. D. 1995. "The Influence of International Risk on Entry Mode Strategy in the Computer Software Industry." Management International Review (MIR) 35(1): 7-28.

Brouthers, K. D. 2013. "A retrospective on: Institutional, cultural and transaction cost influences on entry mode choice and performance." Journal of International Business Studies 44(1): 14-22.

Brouthers, K.D., L.E. Brouthers, and S. Werner. 2002. "Industrial sector, perceived environmental uncertainty and entry mode strategy." Journal of Business Research 55(6): 495-507.

Brouthers, K. D., L.E. Brouthers, and S. Werner. 2008. "Resource-Based Advantages in an International Context." Journal of Management 34(2): 189-217.

Buckley, P. and M. Casson. 1976. The future of the multinational corporation. London: Macmillan.

Buckley, P. and Casson, M. 1998. "Analyzing foreign market entry strategies: Extending the internalization approach.” Journal of International Business Studies 29(3): 539-561.

Busse, M. and C. Hefeker. 2007. "Political risk, institutions and foreign direct investment." European Journal of Political Economy 23(2): 397-415.

Chauhan, P., S. Kumar, R.K. Sharma. 2015. "Modeling Drivers of Political Risk in Offshore Outsourcing.” European Journal of Business and Management, 7(9): 34-44.

Coase, R. H. 1937. "The Nature of the Firm.” Economica 4(16): 386-405.

Contractor, F., V. Kumar, S. Kundu, and T. Pedersen. 2010. "Reconceptualizing the Firm in a World of Outsourcing and Offshoring: The Organizational and Geographical Relocation of High-Value Company Functions.” The Journal of Management Studies 47(8): 1417.

Cui, Z. 2017. "The Impact of Switching Costs on the Outsourcing of Knowledge-Intensive Business Processes.” Decision Sciences 48(1): 71-107.

Dekkers, R. 2000. "Decision models for outsourcing and core competencies in manufacturing." International Journal of Production Research 38(17): 4085-4096.

Dekkers, R. 2011. "Impact of strategic decision making for outsourcing on managing manufacturing." International Journal of Operations \& Production Management 31(9): 935965.

Demirbag, M. and K. W. Glaister. 2010. "Factors determining offshore location choice for R\&D projects: A comparative study of developed and emerging regions." Journal of Management Studies 47(8): 1534-1560. 
Dolgui, A. and J. M. Proth. 2013. "Outsourcing: definitions and analysis." International Journal of Production Research 51(23-24): 6769-6777.

Dunning, J. H. 1980. "Toward an Eclectic Theory of International Production: some Empirical Tests.” Journal of International Business Studies 11(1): 9-31.

Dunning, J. H. 2000. "The eclectic paradigm as an envelope for economic and business theories of MNE activity.” International Business Review 9(2): 163-190.

Ellram, L.M., W.L. Tate, and C. Billington, 2008. "Offshore outsourcing of professional services: A transaction cost economics perspective.” Journal of Operations Management 26(2): 148-163. Espino-Rodríguez, T. F. and V. Padrón-Robaina. 2006. "A review of outsourcing from the resource-based view of the firm." International Journal of Management Reviews 8(1): 49-70.

Erramilli, M. K. 1992. "Influence of some external and internal environmental factors on foreign market entry mode choice in service firms." Journal of Business Research 25(4): 263-276.

Frynas, J., K. Mellahi, and G.A. Pigman. 2006. "First mover advantages in international business and firm-specific political resources." Strategic Management Journal 27(4): 321-345.

Fitzpatrick, M. 1983. "The definition and assessment of political risk in international business: A review of the literature." Academy of Management Review 8(2): 249-254.

Gopal, A. and B.R. Koka. 2010. "The role of contracts on quality and returns to quality in offshore software development outsourcing." Decision Sciences 41(3): 491-516.

Graf, M. and S.M. Mudambi. 2005. "The outsourcing of IT-enabled business processes: A conceptual model of the location decision." Journal of International Management 11(2): 253268.

Hahn, E.D., Doh, J.P., Bunyaratavej, K. 2009. “The evolution of risk in information systems offshoring: The impact of home country risk, firm learning, and competitive dynamics." MIS Quarterly: Management Information Systems, 33 (3): 597-616.

Hair, J. F., W.C. Black, B.J. Babin, and R.E. Anderson. 2011. Multivariate Data Analysis. 7th edition. People's Republic of China: China Machine Press.

Hätönen, J. and T. Eriksson. 2009. "30+ years of research and practice of outsourcing-Exploring the past and anticipating the future." Journal of International Management 15(2), 142-155.

Hansen, C., C. Mena, and H. Skipworth. 2017. "Exploring political risk in offshoring engagements." International Journal of Production Research 55: 1-17. 
Hennart, J. F. 1993. "Explaining the swollen middle: Why most transactions are a mix of "market" and 'hierarchy"'. Organization Science 4(4): 529-547.

Henisz, W. J. 2000. "The institutional environment for multinational investment." Journal of Law, Economics and Organization 16(2): 334-364.

International Monetary Fund (IMF). 2007. Balance of Payments and International Investment Position Manual, Sixth Edition (BPM6). https://www.imf.org/external/pubs/ft/bop/ 2007/pdf/bpm6.pdf

Jahns, C., E. Hartmann, and L. Bals. 2006. "Offshoring: Dimensions and diffusion of a new business concept." Journal of Purchasing and Supply Management, 12(4): 218-231.

Kotabe, M. and J.Y. Murray. 2004. "Global sourcing strategy and sustainable competitive advantage." Industrial Marketing Management 33(1), 7.

Kulkarni, S. P. 2001. "The influence of the type of uncertainty on the mode of international entry." American Business Review 19(1): 94-101.

Kull, T.J., A. Oke, and K.J. Dooley. 2014. "Supplier selection behavior under uncertainty: contextual and cognitive effects on risk perception and choice." Decision Sciences 45(3): $467-$ 505 .

Larsen, M.M., S. Manning, T. and Pedersen. 2013. "Uncovering the hidden costs of offshoring: The interplay of complexity, organizational design, and experience." Strategic Management Journal 34(5): 533-552.

Li, Y., Z. Wei, and Y. Liu. 2010. "Strategic Orientations, Knowledge Acquisition, and Firm Performance: The Perspective of the Vendor in Cross-Border Outsourcing." Journal of Management Studies, 47(8): 1457-1482.

López-Duarte, C. and M.M. Vidal-Suárez. 2010. "External uncertainty and entry mode choice: Cultural distance, political risk and language diversity." International Business Review, 19(6): $575-588$.

Luo, Y., S.L. Wang, Q. Zheng, and V. Jayaraman. 2012. "Task attributes and process integration in business process offshoring: A perspective of service providers from India and China." Journal of International Business Studies, 43(5): 498-524. 
Madhok, A. 2002. "Reassessing the Fundamentals and Beyond: Ronald Coase, the Transaction Cost and Resource-based Theories of the Firm and the Institutional Structure of Production." Strategic Management Journal 23(6): 535-550.

Miller, K. D. 1992. “A Framework for Integrated Risk Management in International Business.” Journal of International Business Studies 23(2): 311.

Mishra, A., K.K. Sinha, and S. Thirumalai. 2017. "Project Quality: The Achilles Heel of

Offshore Technology Projects?" IEEE Transactions on Engineering Management, 64(3): 272286.

Peng, M. W., D. Y. Wang, and Y. Jiang. 2008. "An institution-based view of international business strategy: A focus on emerging economies." Journal of International Business Studies 39(5): 920936.

Political Risk Services Group (PRSG), International Country Risk Guide (ICRG) period 19882014. http://epub.prsgroup.com/products/international-country-risk-guide-icrg.

Slangen, A. H. L., and R. J. M. V. Tulder. 2009. "Cultural distance, political risk, or governance quality? Towards a more accurate conceptualization and measurement of external uncertainty in foreign entry mode research.” International Business Review 18(3): 276-291.

United Nations Conference on Trade and Development (UNCTAD), Foreign Direct Investment Flows and Stock - Inward and outward foreign direct investment flows, annual, 1970-2013. http://unctad.org/en/Pages/DIAE/FDI\%20Statistics/FDI-Statistics.aspx. Accessed 26 February 2015.

Van Wyk, J. 2010. "Political Sources of International Business Risk: an Interdisciplinary Framework.” Journal of International Business Research 9(1): 103-119.

Werner, S., L. E. Brouthers, and K. D. Brouthers. 1996. "International Risk and Perceived Environmental Uncertainty: The Dimensionality and Internal Consistency of Miller's Measure.” Journal of International Business Studies 27(3): 571-587.

Wernerfelt, B. 1984. “A resource-based view of the firm.” Strategic Management Journal 5(2): 171-180.

Williamson, O. E. 1975. Markets \& Hierarchies: Analysis \& Anti-Trust Implications. The Free Press, New York, NY. 
Williamson, O. E. 1985. The Economic Institutions of Capitalism, 1st ed., The Free Press, New York, USA.

Williamson, O. E. 2008. "Outsourcing: Transaction Cost Economics and Supply Chain Management." Journal of Supply Chain Management 44(2): 5-16.

World Economic Forum (WEF) 2014. The Global Competitiveness Report 2014-2015. The Global Competitiveness and Benchmarking Network. http://www3.weforum.org/docs/ WEF_GlobalCompetitivenessReport_2014-15.pdf. Accessed 17 January 2016.

World Trade Organization (WTO) 2005. World Trade Report 2005, III Thematic Essays, C. Offshoring Services: Recent Developments and Prospects. https://www.wto.org/english/ res_e/booksp_e/anrep_e/world_trade_report05_e.pdf. Accessed 4 February 2016.

Zhao, H., Y. Luo, and T. Suh. 2004. "Transaction cost determinants and ownership-based entry mode choice: a meta-analytical review." Journal of International Business Studies 35(6): 524544. 


\section{Appendix 1: Overview of country samples across offshore outsourcing activities}

\begin{tabular}{|c|c|c|c|}
\hline BOP Classification & $\begin{array}{c}\text { Outsourcing } \\
\text { Type }\end{array}$ & $\begin{array}{l}\mathbf{N} \\
\text { size }\end{array}$ & Country Samples \\
\hline $\begin{array}{l}\text { Aggregate BOP Services } \\
\text { Credit; Computer and } \\
\text { Information Services (CIS), } \\
\text { Research \& Development } \\
\text { Services and Other } \\
\text { Business Services }\end{array}$ & $\begin{array}{c}\text { Offshore } \\
\text { Outsourcing } \\
\text { (Aggregate ITO, } \\
\text { BPO, and KPO } \\
\text { (R\&D)) }\end{array}$ & 92 & $\begin{array}{l}\text { Albania, Algeria, Argentina, Armenia, Australia, Austria, Azerbaijan, } \\
\text { Bahrain, Bangladesh, Belgium, Bolivia, Botswana, Brazil, Bulgaria, } \\
\text { Cameroon, Canada, China, Colombia, Costa Rica, Croatia, Cyprus, Czech } \\
\text { Republic, Dominican Rep., Egypt, El Salvador, Estonia, Ethiopia, } \\
\text { Finland, France, Germany, Ghana, Greece, Guatemala, Guyana, } \\
\text { Honduras, Hungary, India, Ireland, Israel, Italy, Jamaica, Jordan, } \\
\text { Kazakhstan, Korea Republic, Latvia, Lithuania, Luxembourg, Malawi, } \\
\text { Malta, Mongolia, Morocco, Mozambique, Namibia, Netherlands, New } \\
\text { Zealand, Nicaragua, Nigeria, Norway, Oman, Pakistan, Panama, } \\
\text { Paraguay, Peru, Philippines, Poland, Portugal, Romania, Russia, Saudi } \\
\text { Arabia, Senegal, Singapore, Serbia Republic, Slovakia, Slovenia, South } \\
\text { Africa, Spain, Sri Lanka, Sweden, Switzerland, Tanzania, Thailand, } \\
\text { Trinidad \& Tobago, Tunisia, Turkey, Uganda, Ukraine, United Kingdom, } \\
\text { United States, Uruguay, Venezuela, Yemen, Republic, Zambia }{ }^{1} \text {. }\end{array}$ \\
\hline $\begin{array}{l}\text { Services, Other Business } \\
\text { Services, Technical, trade- } \\
\text { related, and other business } \\
\text { services }\end{array}$ & BPO & 92 & (same as above) \\
\hline $\begin{array}{l}\text { Computer and Information } \\
\text { Services (CIS) }\end{array}$ & ITO & 61 & $\begin{array}{l}\text { Albania, Algeria, Argentina, Armenia, Australia, Austria, Azerbaijan, } \\
\text { Bangladesh, Belgium, Bolivia, Botswana, Brazil, Bulgaria, Canada, } \\
\text { Colombia, Costa Rica, Cyprus, Czech Republic, Dominican Rep., El } \\
\text { Salvador, Estonia, Finland, Germany, Greece, Guatemala, Guyana, } \\
\text { Hungary, India, Ireland, Israel, Italy, Jamaica, Kazakhstan, Korea } \\
\text { Republic, Latvia, Lithuania, Malta, Mongolia, Morocco, Mozambique, } \\
\text { Namibia, Nicaragua, Norway, Pakistan, Panama, Philippines, Poland, } \\
\text { Portugal, Romania, Russia, Serbia Republic, Slovakia, Slovenia, Sri } \\
\text { Lanka, Sweden, Tanzania, Tunisia, Uganda, Ukraine, United States, } \\
\text { Uruguay. }\end{array}$ \\
\hline $\begin{array}{l}\text { Services, Other Business } \\
\text { Services, Research and } \\
\text { Development Services }\end{array}$ & KPO (R\&D) & 43 & $\begin{array}{l}\text { Albania, Argentina, Australia, Austria, Azerbaijan, Bangladesh, Belgium, } \\
\text { Botswana, Brazil, Bulgaria, Canada, Costa Rica, Croatia, Cyprus, Czech } \\
\text { Republic, Estonia, Ethiopia, Finland, Germany, Greece, Hungary, India, } \\
\text { Ireland, Italy, Korea Republic, Latvia, Lithuania, Malawi, Malta, New } \\
\text { Zealand, Norway, Pakistan, Philippines, Poland, Portugal, Romania, } \\
\text { Russia, Singapore, Serbia Republic, Slovenia, Spain, Ukraine, USA². }\end{array}$ \\
\hline
\end{tabular}

\footnotetext{
${ }^{1}$ Note that complete data sets were not available for typical offshore outsourcing destinations such as Indonesia, Malaysia and Mexico hence they are not included in the analysis.

${ }^{2}$ Note that R\&D data were not available for large economies such as the United Kingdom, France and Japan.
} 
Table 1: Description of political risk independent variables (Time series 2006-2014)

\begin{tabular}{|l|l|l|l|l|}
\hline No & Risk Indicator Category & Data Source & Definition & N \\
\hline 1. & Quality of bureaucracy & PRS Group & Quality of (Institutional) Bureaucracy & 828 \\
\hline 2. & Burden of customs procedures & WEF/GCI & Burden of customs procedures & 729 \\
\hline 3. & Intellectual property protection & WEF/GCI & Level of IP protection & 723 \\
\hline 4. & Corruption & WEF/GCI & Corruption levels at host location & 819 \\
\hline 5. & Contract enforcement & WEF/GCI & $\begin{array}{l}\text { Local legal system's ability to enforce } \\
\text { contracts }\end{array}$ & 549 \\
\hline 6. & Currency fluctuations & PRS Group & Stability of local currency & 827 \\
\hline 7. & Organised labour strike & WEF/GCI & Disruption through local strikes & 814 \\
\hline 8. & Host government stability & PRS Group & Changes in Government policies & 828 \\
\hline 9. & Judicial independence & WEF/GCI & Judiciary independence from influence & 814 \\
\hline 10. & Internal conflict & PRS Group & Risk of internal conflict and violence & 828 \\
\hline 11. & Geopolitical risk & PRS Group & Regional instability affecting business & 828 \\
& & & continuity & Perceived risk and costs in securing staff \\
\hline 12. & Staff security & security & 814 \\
\hline
\end{tabular}


Table 2: Dependent variables and time series intervals

\begin{tabular}{|c|c|c|c|}
\hline & Variable Name & Period & Definition of Data Source \\
\hline 1. & $\begin{array}{l}\text { Aggregated Service offshore } \\
\text { outsourcing (outsourcing) per } \\
\text { national economy. }\end{array}$ & $2006-2014$ & $\begin{array}{l}\text { Export (Credit) of Aggregate BoP Services Credit; } \\
\text { Computer and Information Services (CIS), Research \& } \\
\text { Development Services and Other Business Services as } \\
\text { per annual BOP6. }\end{array}$ \\
\hline 2. & $\begin{array}{l}\text { ITO export per national } \\
\text { economy. }\end{array}$ & $2006-2014$ & $\begin{array}{l}\text { Export (Credit) of Services, Computer and Information } \\
\text { Services (CIS) as per annual BOP6. }\end{array}$ \\
\hline 3. & $\begin{array}{l}\text { BPO export per national } \\
\text { economy. }\end{array}$ & $2006-2014$ & $\begin{array}{l}\text { Export (Credit) of Services, Other Business Services, } \\
\text { Technical, trade-related, and other business services as } \\
\text { per annual BOP6. }\end{array}$ \\
\hline 4. & $\begin{array}{l}\text { KPO (R\&D) export per } \\
\text { national economy. }\end{array}$ & $2006-2014$ & $\begin{array}{l}\text { Export (Credit) of Services, Other Business Services, } \\
\text { Research and Development Services) as per annual } \\
\text { BOP6. }\end{array}$ \\
\hline 5 . & $\begin{array}{l}\text { Foreign Direct Investment } \\
\text { (FDI) inflow per national } \\
\text { economy (captive offshoring) }\end{array}$ & $2006-2014$ & UNCTAD FDI database (2014) - Net FDI inflows. \\
\hline
\end{tabular}


Table 3: Ranking of political risk indicators (aggregate global offshore outsourcing flows)

\begin{tabular}{|l|c|c|c|}
\hline Indicator Description & Beta & t-value & Sig. \\
\hline Intellectual property protection & 0.692 & $5.789 * * *$ & .000 \\
\hline Burden of customs procedures & -0.379 & $-4.783^{* * *}$ & .000 \\
\hline Quality of bureaucracy & 0.305 & $4.260^{* * *}$ & .002 \\
\hline Internal conflict & -0.167 & $-3.158^{* *}$ & .062 \\
\hline Corruption & 0.148 & 1.869 & .371 \\
\hline Contract enforcement & -0.096 & -0.895 & .039 \\
\hline Geopolitical risk & -0.094 & $-2.075^{*}$ & .165 \\
\hline Organised labour strike & 0.076 & 1.391 & .118 \\
\hline Host government stability & -0.068 & -1.567 & .271 \\
\hline Staff security & -0.065 & -1.102 & .605 \\
\hline Judicial independence & -0.053 & -0.518 & .932 \\
\hline Currency fluctuations & 0.003 & 0.085 & \\
\hline
\end{tabular}

\begin{tabular}{|c|c|c|c|c|c|c|}
\hline \multirow{2}{*}{$\mathrm{R}$} & \multirow{2}{*}{ R Square } & Adjusted R Square & $\begin{array}{c}\text { Std. Error of the } \\
\text { Estimate }\end{array}$ & \multicolumn{3}{|c|}{ Change Statistics } \\
\cline { 5 - 7 } & & & & $\begin{array}{c}\text { R Square } \\
\text { Change }\end{array}$ & F Change & df1 \\
\hline .616 & .380 & .363 & 12844416079.70 & .380 & 22.151 & 12 \\
\hline
\end{tabular}

Notes: $* p$-value $<.05 ; * * p$-value $<.01 ; * * * p$-value $<.001$ 
Table 4: Ranking of political risk - impact on offshore outsourcing flows - ITO

\begin{tabular}{|l|c|c|c|}
\hline Indicator Description & Beta & T-value & Sig. \\
\hline Internal conflict & -0.416 & $-5.890^{* * *}$ & .000 \\
\hline Quality of bureaucracy & 0.265 & $2.782^{* *}$ & .006 \\
\hline Burden of customs procedures & -0.260 & $-2.462^{*}$ & .014 \\
\hline Judicial independence & 0.292 & $2.152^{*}$ & .032 \\
\hline Intellectual property protection & 0.291 & 1.828 & .069 \\
\hline Contract enforcement & -0.183 & -1.284 & .200 \\
\hline Organised labour strike & 0.177 & $2.448^{*}$ & .015 \\
\hline Corruption & -0.150 & -1.425 & .155 \\
\hline Host government stability & -0.047 & -0.807 & .421 \\
\hline Staff Security & 0.133 & 1.693 & .091 \\
\hline Geopolitical risk & 0.108 & 1.780 & .076 \\
\hline Currency fluctuations & -0.022 & -0.435 & .664 \\
\hline
\end{tabular}

\begin{tabular}{|c|c|c|c|c|c|c|c|}
\hline \multirow{2}{*}{$\begin{array}{l}\text { Offshore } \\
\text { Activity }\end{array}$} & \multirow[t]{2}{*}{$\mathrm{R}$} & \multirow[t]{2}{*}{ R Square } & \multirow{2}{*}{$\begin{array}{l}\text { Adjusted R } \\
\text { Square }\end{array}$} & \multicolumn{3}{|c|}{ Change Statistics } & \multirow{2}{*}{$\begin{array}{l}\text { Durbin- } \\
\text { Watson }\end{array}$} \\
\hline & & & & R Square Change & F Change & df1 & \\
\hline ITO & .517 & .267 & .237 & .267 & 8.782 & 12 & .401 \\
\hline
\end{tabular}

Notes: ${ }^{*} p$-value $<.05 ; * * p$-value $<.01 ; * * * p$-value $<.001$ 
Table 5: Ranking of political risk - impact on offshore outsourcing flows - BPO

\begin{tabular}{|l|c|c|c|}
\hline Indicator Description & Beta & T-value & Sig. \\
\hline Intellectual property protection & 0.744 & $6.157^{* * *}$ & .000 \\
\hline Burden of customs procedures & -0.329 & $-4.103^{* * *}$ & .000 \\
\hline Judicial independence & -0.245 & $-2.377^{*}$ & .018 \\
\hline Quality of bureaucracy & 0.241 & $3.336^{* *}$ & .001 \\
\hline Corruption & 0.200 & $2.500^{* *}$ & .013 \\
\hline Geopolitical risk & -0.154 & $-3.361^{* *}$ & .001 \\
\hline Staff security & -0.116 & -1.947 & .052 \\
\hline Host government stability & -0.084 & -1.910 & .057 \\
\hline Internal conflict & -0.070 & -1.299 & .195 \\
\hline Contract enforcement & 0.063 & 0.585 & .559 \\
\hline Organised labour strike & 0.013 & 0.237 & .813 \\
\hline Currency fluctuations & 0.008 & 0.211 & .833 \\
\hline
\end{tabular}

\begin{tabular}{|c|c|c|c|c|c|c|c|}
\hline \multirow{2}{*}{$\begin{array}{l}\text { Offshore } \\
\text { Activity }\end{array}$} & \multirow[t]{2}{*}{$\mathrm{R}$} & \multirow{2}{*}{ R Square } & \multirow{2}{*}{$\begin{array}{c}\text { Adjusted R } \\
\text { Square }\end{array}$} & \multicolumn{3}{|c|}{ Change Statistics } & \multirow{2}{*}{$\begin{array}{l}\text { Durbin- } \\
\text { Watson }\end{array}$} \\
\hline & & & & R Square Change & F Change & $\mathrm{df1}$ & \\
\hline $\mathrm{BPO}$ & .606 & .368 & .350 & .368 & 20.980 & 12 & .501 \\
\hline
\end{tabular}

Notes: ${ }^{*} p$-value $<.05 ; * * p$-value $<.01 ; * * * p$-value $<.001$ 
Table 6: Ranking of political risk - impact on offshore outsourcing flows - KPO

\begin{tabular}{|l|c|c|c|}
\hline Indicator Description & Beta & T-value & Sig. \\
\hline Intellectual property protection & 0.935 & $4.936^{* * *}$ & .000 \\
\hline Burden of customs procedures & -0.505 & $-4.017^{* * *}$ & .000 \\
\hline Staff security & -0.265 & $-2.823^{* *}$ & .005 \\
\hline Quality of bureaucracy & 0.206 & 1.816 & .071 \\
\hline Contract enforcement & -0.196 & -1.157 & .249 \\
\hline Corruption & 0.195 & 1.559 & .120 \\
\hline Judicial independence & -0.180 & -1.112 & .267 \\
\hline Organised labour strike & 0.078 & 0.909 & .364 \\
\hline Host government stability & 0.105 & 1.528 & .128 \\
\hline Geopolitical risk & -0.052 & -0.717 & .474 \\
\hline Currency fluctuations & 0.048 & 0.782 & .435 \\
\hline Internal conflict & -0.014 & -0.164 & .870 \\
\hline
\end{tabular}

\begin{tabular}{|c|c|c|c|c|c|c|c|}
\hline \multirow{2}{*}{$\begin{array}{l}\text { Offshore } \\
\text { Activity }\end{array}$} & \multirow{2}{*}{$\mathrm{R}$} & \multirow{2}{*}{$\begin{array}{c}\mathrm{R} \\
\text { Square }\end{array}$} & \multirow{2}{*}{$\begin{array}{l}\text { Adjusted R } \\
\text { Square }\end{array}$} & \multicolumn{3}{|c|}{ Change Statistics } & \multirow{2}{*}{$\begin{array}{l}\text { Durbin- } \\
\text { Watson }\end{array}$} \\
\hline & & & & $\begin{array}{l}\text { R Square } \\
\text { Change }\end{array}$ & F Change & df1 & \\
\hline KPO & .527 & .277 & .234 & .277 & 6.429 & 12 & .293 \\
\hline
\end{tabular}

Notes: ${ }^{*} p$-value $<.05 ; * * p$-value $<.01 ; * * * p$-value $<.001$ 
Table 7: Ranking of political risk indicators in captive offshoring flows

\begin{tabular}{|l|c|c|c|}
\hline \multicolumn{1}{|c|}{ Indicator Description } & Beta & T-value & Sig. \\
\hline Intellectual property protection & 0.733 & $5.806^{* * *}$ & .000 \\
\hline Judicial independence & -0.353 & $-3.272^{* *}$ & .001 \\
\hline Burden of customs procedures & -0.312 & $-3.727^{* * *}$ & .000 \\
\hline Quality of bureaucracy & 0.269 & $3.554^{* * *}$ & .000 \\
\hline Corruption & 0.215 & $2.576^{*}$ & .010 \\
\hline Staff security & -0.184 & $-2.943^{* *}$ & .003 \\
\hline Geopolitical risk & -0.154 & $-3.201 * *$ & .001 \\
\hline Contract enforcement & 0.059 & 0.522 & .602 \\
\hline Currency fluctuations & 0.015 & 0.358 & .721 \\
\hline Organised labour strike & -0.013 & -0.219 & .827 \\
\hline Host government stability & 0.003 & 0.075 & .940 \\
\hline Internal conflict & 0.001 & 0.025 & .980 \\
\hline
\end{tabular}

\begin{tabular}{|c|c|c|c|c|c|c|}
\hline \multirow{2}{*}{$\mathrm{R}$} & \multirow{2}{*}{ R Square } & Adjusted R Square & $\begin{array}{c}\text { Std. Error of the } \\
\text { Estimate }\end{array}$ & \multicolumn{3}{|c|}{ Change Statistics } \\
\cline { 5 - 7 } & & & & $\begin{array}{c}\text { R Square } \\
\text { Change }\end{array}$ & F Change & df1 \\
\hline .539 & .291 & .272 & 370924.63 & .291 & 15.185 & 12 \\
\hline
\end{tabular}

Notes: $* p$-value $<.05 ; * * p$-value $<.01 ; * * * p$-value $<.001$ 
Table 8: Hypotheses tested and conclusions

\begin{tabular}{|c|c|c|}
\hline Hypothesis & Evidence & Conclusion \\
\hline $\begin{array}{l}\text { H1: The political risk } \\
\text { factors that affect } \\
\text { offshoring decisions for } \\
\text { offshore outsourcing } \\
\text { activities are different } \\
\text { from those that affect } \\
\text { captive offshoring } \\
\text { activities. }\end{array}$ & $\begin{array}{l}\text { Four political risk factors (Intellectual } \\
\text { Property (IP) protection, Burden of customs } \\
\text { procedures, Quality of bureaucracy, Internal } \\
\text { conflict) are significant in explaining the } \\
\text { variation in the volume of offshore } \\
\text { outsourcing activities [Table 3] } \\
\text { Whereas seven out of } 12 \text { political risk } \\
\text { factors (Intellectual Property (IP) protection, } \\
\text { Judicial independence, Burden of customs } \\
\text { procedures, Quality of bureaucracy, } \\
\text { Corruption, Staff security, and Geopolitical } \\
\text { risk) are significant in explaining the } \\
\text { variation in the volume of captive } \\
\text { offshoring activities. }\end{array}$ & $\begin{array}{l}\text { Partially supported. } \\
\text { The findings suggest that the combined } \\
\text { political risk variables account for a } \\
\text { total of } 38.0 \% \text { of the variation in } \\
\text { offshore outsourcing, compared to } \\
29.1 \% \text { of the variation in captive } \\
\text { offshoring flows. } \\
\text { Although fewer of the political risk } \\
\text { factors are significant for aggregate } \\
\text { offshore outsourcing volume, they can } \\
\text { explain more of the variability in } \\
\text { offshoring volumes. }\end{array}$ \\
\hline $\begin{array}{l}\text { H2: Institutional and } \\
\text { regulatory factors in the } \\
\text { host country are } \\
\text { positively related to the } \\
\text { volume of offshore } \\
\text { outsourcing activities. }\end{array}$ & $\begin{array}{l}\text { Eight of the } 12 \text { institutional and regulatory } \\
\text { factors of political risk are found to be } \\
\text { significant in separate regressions for ITO, } \\
\text { BPO, and KPO. } \\
\text { Among these are Corruption, Geopolitical } \\
\text { risk, Intellectual Property (IP) protection, } \\
\text { Internal conflict, Quality of bureaucracy, } \\
\text { and Staff security, being positively related } \\
\text { to the volume of offshoring. Two variables, } \\
\text { Judicial independence and Burden of } \\
\text { customs procedures are negatively related to } \\
\text { the volume of offshoring activities. }\end{array}$ & $\begin{array}{l}\text { Partially supported. } \\
\text { This result provides the granularity in } \\
\text { understanding the effect of factors that } \\
\text { constitute political risk on the volume } \\
\text { of offshore outsourcing activities. The } \\
\text { results support that political risk is a } \\
\text { multidimensional construct, with bi- } \\
\text { directional effect on offshoring } \\
\text { volumes. }\end{array}$ \\
\hline $\begin{array}{l}\text { H3: Institutional and } \\
\text { regulatory factors in the } \\
\text { host country are } \\
\text { positively related to the } \\
\text { volume of offshore } \\
\text { outsourcing activities } \\
\text { with a higher knowledge } \\
\text { content (KPO). }\end{array}$ & $\begin{array}{l}\text { Although Intellectual Property (IP) } \\
\text { protection is positively related to the volume } \\
\text { of KPO activities, the other two significant } \\
\text { factors, namely: Burden of customs } \\
\text { procedures and Staff security, are negatively } \\
\text { related to the volume. Discussion of this } \\
\text { result follows. }\end{array}$ & $\begin{array}{l}\text { Partially supported. } \\
\text { This result sheds light on the individual } \\
\text { effects of } 12 \text { factors that comprise the } \\
\text { political risk concept. Previously } \\
\text { political risk was used as a holistic } \\
\text { explanatory variable for offshoring } \\
\text { location decisions; now we find support } \\
\text { and the lack of support for individual } \\
\text { factors that make up the political risk; } \\
\text { hence providing a more detailed } \\
\text { explanation of how it impacts } \\
\text { offshoring location decisions. }\end{array}$ \\
\hline
\end{tabular}

